\title{
The present situation of animal protein in Egypt and the role of camels in providing cheap and healthy meat for people in poor greenery lands
}

\begin{abstract}
Background: In Egypt (Semi-arid country), there is a great developing gab between public demands and available amounts of animal protein (especially the red meat protein) due to many environmental conditions and managerial practices. Therefore, the need for fattening male dromedary camels could be a promising solution to overcome this problem. Camels are a good source of economic meat this is because of its unique tolerance to high environmental temperatures, solar radiation, water scarcity and poor vegetarian, beside its high efficiency in the metabolic process. The maintenance requirements of energy and protein are much lower than other ruminants. Camel produces a large quantities of meat and consume less amounts of feeds than other farm animals (1.5-2.0 kg feed intake per $100 \mathrm{~kg}$ body weight and can gain $800-1000 \mathrm{~g} /$ day). The dressing percentage of wellfed slaughtered camels is $56-62 \%$. Meat of fattened camel calves (2-3 years of age) is comparable in color, texture and taste to that of young beef cattle. Moreover, camel's meat is rich in protein content, iron, vitamin B but low in fat $(>5 \%)$ and cholesterol. There are many other health benefits of camel's meat due to its high content of glycogen, unsaturated fatty acids like linoleic acid and essential amino acids. It's highly recommended to give great attention to camels as cheap and healthy meat providers.
\end{abstract}

Keywords: dromedary camels, fattening, camels' meat properties, benefit health of camel meat, greenery
Volume 3 Issue 4 - 2018

\begin{abstract}
Alaa YEl Badawi
Animal Production Department, National Research Centre, Egypt

Correspondence: Alaa YEl Badawi, Animal Production Department, National Research Centre, Dokki, Giza, PO BoxI2622, Egypt, Email duckily@hotmail.com
\end{abstract}

Received: February 03, 2018 | Published: August 22, 2018

\section{Introduction}

In Egypt, there is a great developing gap between public annual demands and available amounts of animal protein. The daily available protein of animal origin is nearly $18.2 \mathrm{~g} / \mathrm{cap} /$ day. This amount is too far from $29.3 \mathrm{~g} / \mathrm{cap} /$ day which has been recommended by the FAO since 1989 as a minimum requirement of animal protein/cap/day for people in the developing countries. In this concern, a task mission was decided by the governmental authorities in charge to reach $24 \mathrm{~g} / \mathrm{cap} /$ day by year 2017. The following table shows the annual production of animal protein in year 2007 and the forecast production on year 2017 (Table 1).

Table I Annual production of animal protein in year 2007 and the forecast production on year 2017

\begin{tabular}{llll}
\hline Item & Unit & $\mathbf{2 0 0 7}$ & $\mathbf{2 0 1 7}$ \\
\hline Milk & Million tons & 4 & 6.2 \\
Fish & Thousand tons & 680 & 1500 \\
Table eggs & Billion eggs & 7 & 10.6 \\
Poultry & Million chicks & 700 & 1200 \\
Red meat & Thousand tons & 560 & 880
\end{tabular}

(Cited from statistics of The Egyptian Ministry of Agriculture and Land Reclamation, 2007-2017).

During the last 10 years, a tangible improvement has been achieved with poultry (eggs-meat) products and aqua-culture fish production, while the red meat production from local breeds didn't attain any marked progress. Therefore, about 350,000 tons of fresh and frozen meat is now annually imported. The problem of red meat protein insufficiency is a resultant of many factors negatively influencing policies of beef and mutton meat production being as follows: a) Limited availability of irrigated water particularly in the newly reclaimed lands.

b) Limited agricultural land area and poor natural ranges.

c) Shortage in production of cereal and legume grains.

d) Inadequacy of green fodders particularly in summer season.

e) Low genetic make-up of local breeds due to unsuccessful selection and culling program application.

f) Limited efforts of veterinary care units particularly in south and desert regions.

g) Poor technical support and extension programs oriented to animal breeders and small farmers who are holding about $95 \%$ of animal wealth.

h) Unstable market prices of animal products and continuous inflation of feedstuff prices.

So, it's a target necessary to give attention to other untraditional type of animals capable survive and produce meat under harsh conditions including poor availability of good quality forages, high salinity underground drinking water, hot climate and need lower energy and protein requirements for growth than cattle and other small ruminants. Under such circumstances camels could be the most promising animal in resolving the problem of red meat protein insufficiency.

\section{Importance of camels as meat providers in some African and Arab countries}

Camels occupied a very important role in providing an important part of human food, especially meat, in order to fulfill the shortfall in the increasing demand for meat due to the rapid growth of human 
population and the increase of the demand for the foodstuffs. For this, majority of nations, particularly in some parts of Asia and Africa started it suffers from a lack of animal protein (especially the meat) and starvation began to increase in poor people, therefore the need became very urgent to increase the care for the animal husbandry for the purpose to increase the animal production, especially the care for camels breeding. The dromedary camel is a good source of meat especially in areas where the climate adversely affects the performance of other meat animals. This is because of its unique physiological characteristics, including a great tolerance to high temperatures, solar radiation, water scarcity, rough topography and poor vegetation. The camels are also characterized by its high efficiency in the metabolism process this is because camels have the ability to transform the low quality plants (poor desert plants, thorny plants and the branches of the hard tress) with minimal nutritive elements, into high quality food products. The demand for camel meat appears to be increasing due to health reasons, as they produce carcasses with less fat as well as having less cholesterol and relatively high polyunsaturated fatty acids than other meat animals. There are 24,246,291 million one-humped camels in the world with $80 \%$ of them in Africa and the highest population in Somalia (7 million) and Sudan (4.25 million). In Asia about $70 \%$ of dromedaries are found in India and Pakistan.

Camel produces a large quantities of meat compared to other farm animals, where the weight of a camel between $350-700 \mathrm{~kg}$ and the proportion of camel net meat is high as it varies by different factors such as age, type of nutrition and type of breeding, ranging from $43.6-62.7 \%$ and the proportion of fat and bones are zero- $4.8 \%$ and $15.9-38.1 \%$ respectively. Camel's meat is a very important in arid and semi-arid regions in the world, where it constitutes an important resource for some countries such as Sudan, Somalia and Mauritania, as camels are considered more efficient than the other farm animals in the production of meat, where it represent about $8 \%$ of the meat production in the Arab countries.

Male camels are slaughtered when they are 1-3 or even 4-5 years old, which is considered their best age for meat production. As they grow older, their meat becomes tougher and loses quality because of old fibers and muscles. Camel meat is known for its large muscular fibers and high percentage of water. It has a little sweet taste because of the presence of glycogen, and its color is red or dark brown. The production quantity of camel meat in the world has reached 351,548 tons/year. Africa (249206 tons/year) and Asia (102253 tons/year) have been formed $99 \%$ of the production in the world. Sudan (49882 tons/year), Egypt (45000 tons/year), Somalia (44200 tons/year), Mauritania (22500 tons/year), United Arab Emirates (19853 tons/ year).

\section{General characteristics of camel meat}

The chemical composition and food value of camel meat have shown that it has two qualities which distinguish it from beef and mutton: its low fat and high moisture content. Fat in camel meat amounts to 1.2 per cent- 1.8 per cent and in beef 4 per cent- 8 per cent. The Camel meat contains a high ratio of good quality protein. Camel meat is also a good source to many vitamins, especially vitamin B complex and important minerals such as iron, calcium and phosphorus. Camel meat is also characterized by low level of cholesterol (61 mg) as compared to other farm animals like beef (75$86 \mathrm{mg}$ ), making it a healthy food for humans. In comparison with the beef, camel meat is rich in the amino acids that are necessary to humans. Camel meat, especially young calves is similar in taste and texture to beef. The amino acids contents of camel meat are often higher than beef, probably due to lower intramuscular fat levels. In addition to that, the intersection of the fat within the muscles gives the marble appearance of the meat and improves its taste and food characteristics. Camel meat contains a high percentage of glycogen, so that it is used in many food industries such as mortadella, sausage, corned beef, sausages and shwarma. The meat of the old camels is hard and contain thick fibers, therefore they do not grill well on the fire or ripen easily when cooking, and that because of the increased strength of the interdependence between the fibers which reduces their vulnerability to heat and enzymes, for this reason are often advised slaughtered young camels that the meat more soft, and better taste than adult camels or aged. The camel meat is characterized by a red color and tasty which is similar to beef, especially smaller ones. The meat fat is creamy with yellow color and soft, smooth as compared to other farm animals. It was approved by many scientists that, there is a close relationship between cardiovascular diseases and increase intake of saturated fatty acids which are present in the fat of beef, buffalo, sheep and goats. The flavor of meat which is preferred by some people is related to the percentage of fat, therefore camel meat has less odor and taste than beef. From a point of health, the nutritional value of camel meat is much better than other animals, due to fact that, camel meat contains a high amount of amino acids compared to the beef.

\section{Some facts about dromedary camels}

It is well known, that camels possess certain unusual physiological features that enable it to thrive in extremely arid environments where normal drinking water and valuable green forages are scarcely available. Camels have exceptional tolerance to heat and water deprivation. They can also concentrate their urine to a marked degree and can re-circulate and reutilize urinary nitrogen when they are deprived of behavioral mechanisms to conserve energy. Camels in its natural habitat can normally consume salt bushes and tolerate high saline water Gihad. ${ }^{1}$ Under desert conditions, camels can drink once a week in summer and every 4-6 weeks in winter. Their maintenance requirement of energy is lower than sheep by nearly $30 \%$ (75 kcal $\mathrm{ME} / \mathrm{kgw} 0.75$ camels Guerouali \& Filali, ${ }^{2}$ Vs. $112 \mathrm{kcal} \mathrm{ME} / \mathrm{kgw} 0.75$ for local sheep El-Badawi et al. ${ }^{3}$ Moreover, camels need lower amounts of protein in their diets than other ruminants, since they have an exceptional ability to recycle urea as a source of nitrogen when dietary protein is unavailable.

Several studies reported that camels require less energy and protein for their maintenance balance than other ruminants, and in extreme cases, they are not only decrease feed intake but also reduce their metabolic rate. ${ }^{2,4-6}$ In more recent study, El-Badawi et al., ${ }^{7}$ reported that fecal and urinary nitrogen losses of three years old camels were zero after 11-13 days of starvation. Other studies noted that camels are able to consume and utilize poor quality forages and salty bushes. ${ }^{8-11}$

On the other hand, milk production of dromedary camels is fluctuating to many environmental and managerial conditions. The dam maintained on irrigated pastures could yield $5-30 \mathrm{~kg}$ milk/ day, while it yields 3-10 kg/day on poor desert range. The dam fed on supplements of corn or barley produce more milk than without supplemental feeds. The average length of lactations in the camels is 12 months, but it may vary from 9 to 18 months. The average seasonal lactation is 1500 to $4900 \mathrm{~kg}$ for 305 days. The camels milk has a sweet taste, but sometimes it tastes salty. The taste is affected by type of pasture plants and salinity of drinking water. Camels milk is rich in vit. C, thiamin, immunoglobins and lactopherrin Gihad. ${ }^{1}$ Camels milk 
can be kept stable for a long period at room temperature. It is known to has a certain therapeutic effects. However, due to the presence of antimicrobial compounds in camel's milk there is some technical difficulties in processing fermented milk and cheese.

\section{Ability of male camels for fattening}

The response of camels to economical fattening was studied by many workers. The results were contradictory; most studied have been done under different feeding systems, different sex and age, limited numbers, short experimental time and different types of desert range plants. Any way; the average daily weight gain was noted to be between 186 to $565 \mathrm{~g}$ for Tunisian male camels Kamoun et al., ${ }^{12}$ and much lower (174-227g) for Indian camels fed rations contained $11.5 \%$ to $12.9 \%$ crude protein. On the contrary, El-Badawi \& Yacout ${ }^{13}$ and Yacout \& El-Badawi ${ }^{14}$ and El-Badawi \& Yacout ${ }^{15}$ recorded average daily weight gain (ADG) between 810 to $840 \mathrm{~g}$ for Sudanese camel calves (2-3 years old) on rations contained 12 to $14 \%$ crude protein. They also noted that the ADG of camels under the feed-lot system was comparable to that of local cattle calves, however the daily DM intake of camels was only $1.44 \%$ of their body weight vs. $2.5 \%$ for cattle calves.

The dressing percentage for well-fed camel calves was in average $58.6 \%$ El-Badawi \& Yacout ${ }^{1}$ which seems comparable to that of cattle steers. Bones are nearly $10 \%$ of the live weight or between 16 to $20 \%$ of the total carcass weight, while fats comprise only $5 \%$ of the total body weight. Meat of young camels is comparable in taste and texture to small cattle beef

\section{Health benefits of camels meat}

In his comprehensive article concerning with the medical properties of camel's meat Kadim ${ }^{16}$ stated that:

1) The camel is distinguished from other animals by the fact that the percentage of its intramuscular fat declines as the animal gets older. This quality, only found in camels, makes their meat less fatty, so its consumption is healthy and recommended for weight loss. And this quality also reduces the risk of cardiovascular disease and atherosclerosis since it lowers the percentage of cholesterol in the blood.

2) Camel meat has other medical qualities, too, like protecting against cancerous tumors, as claimed by some researchers, because it contains unsaturated fatty acids like linoleic acid which interact with other unsaturated fatty acids taken from vegetable oils to protect against cancer.

3) Camel meat can also be used as a cure for exhaustion and fatigue because it contains energy needed by body cells. Such energy comprises sugar not fat, since, a camel's fat is concentrated in its hump whereas other animals store it in their muscles.

4) In addition, camel meat contains glycogen, a carbohydrate which is easily absorbed and metabolized in the body, and is converted to glucose which activates nerve as well as other cells.

5) Another quality which makes it good for the elderly is its richness in glycogen which is converted into glucose and is needed by the nervous system to provide cell energy and thus support the work of nerve cells. It can also provide the elderly with the energy and protein needed to compensate for tissue damage and reproduce hormones and enzymes needed for cell function. This is especially so when catabolism has surpassed anabolism which puts the elderly in need of easily metabolized and digested food likes camel meat.

6) Camel meat prevents obesity and heart disease.

7) Studies have shown that camel meat can be used as a cure for cold and sciatica, stroke, cancer, and infections, especially among older people because this meat can safeguard muscle health. This is due to its low percentage of saturated fatty acids and cholesterol compared to other kinds of meat. In fact the food value of camel meat is higher than poultry meat and equals that of the ostrich.

8) This meat is also known for its high percentage of iron, one of the basic ingredients of blood haemoglobin which helps to reduce the risk of anaemia.

9) Camels meat is also useful for curing seasonal fever, sciatica and shoulder pain. Camels meat soup is used to cure corneal opacity and to strength eyesight, while it's fat is used to ease hemorrhoid. Furthermore, it's hump fat is used to remove tape worm and it's dried lungs is prescribed as a cure for asthma due to its high content of vitamin $\mathrm{C}$ which enhances immunity.

\section{Conclusion}

Under the Egyptian environmental conditions and managerial practices fattening camel calves by applying the intensive feeding system could be a promising solution to overcome the problem of red meat shortage. Dromedary growing male camels consume less amount of feeds $(1.5-2.0 \mathrm{Kg}$ per $100 \mathrm{Kg}$ body weight) than other ruminants and gain daily $800-1000 \mathrm{~g}$ with rations contained $10 \% \mathrm{CP}$ and $2.5 \mathrm{Mcal} \mathrm{ME} / \mathrm{kg}$. The dressing $\%$ of slaughtered well-fed camels is between 56 to 62 and it's meat is rich of protein and iron and low of fat and cholesterol beside that, camel's meat has many medical properties.

\section{Funding details}

The project entitled: Application of Intensive Feeding System on Fattening Camels, has been financed by the Egyptian National Research Centre, through the research plan budget of year 2016-2019.

\section{Conflict of interest}

The author declares that there is no conflict of interest concerning this article.

\section{References}

1. Gihad EA. Arabia Camels. Egypt: Arab Publishing and Distributing Company, Cairo; 1995.

2. Guerouali A, Filali RZ. Maintenance energy requirements of the dromedary camel. Dubai: Proc 1st Intern Camel Conf; 1992. p. 251.

3. El-Badawi AY, Yacout MHM. Comparative study on growth performance of camel calves and cattle steers in the feed lot system. Egyptian J Nutr and Feeds. 1999;3(Special Issue): 319.

4. Knoess KH. The camel as a meat and milk animal. World Anim Rev. 1977;22:39.

5. Gihad EA, El-Bedawy TM. Protein requirement for maintenance by camels. Dubai: Proc 1st Intern, Camel Conf; 1992. p. 412.

6. Farid MFA. Nutrient requirements of dromedary camels: protein and energy requirements for maintenance. $J$ of Arid Environments. 1995;30:2-207. 
7. El-Badawi AY, Yacout MHM, Hassan AA. Experimental determination of maintenance requirements of nitrogen for camels applying balance and fasting trials. Egyptian J Nutr Feeds. 2003;6(Special Issue): 769.

8. Holler R, Lechner M, Weyreter H, et al. Fore stomach fluid volume and retention time of fluid and particles in the gastrointestinal tract of the camel. J Vet Med. 1986;33:396.

9. Rutagwanda T, Lechner M, Schullka HJ. Dietary preference and degradability of forage on a semi-arid thornbuch savannah by indigenous ruminants, camels and donkeys. Anim Feed Sci and Tech. 1990;31:179.

10. Nagpal AK, Singh GP, Arora M. Utilization of mothchara, wheat straw and bui leaves based complete rations in camel calves. Indian J Anim Sci. 2002;19(1):69-72.

11. Shawket SM, Ahmed MH, Ziweil HS. Camel growth performance response to dietary protein levels. Egyptian J Nutr and Feeds. 2007;10:2(Special Issue):477.

12. Kamoun M, Girard P, Beraoui R. Feeding and growth of the dromedary. Effect of concentrate feeding on dry matter intake and growth of camels in Tunisia. AGRIS. 1989;42:89.
13. Yacout MHM, El-Badawi AY. Effect of dietary protein level on fattening performance of camel calves. Egyptian J Nutr and Feeds. 2001;4(Special Issue):545.

14. El-Badawi AY, Mohamed MI, Awadalla IM. Effect of feeding regime on body composition and utilization efficiencies of MEm and NEg for Ossimi lambs during finishing-growth period. Egyptian J Nutr and Feeds. 1999;2(1):17.

15. El-Badawi AY, Yacout MHM. Growth performance and body composition of dromedary camels raised on rations have varying levels of energy: protein ratio. In Proc of the 55th Annual Meeting of the EAAP, Bled, Slovenia. 2004

16. Kadim IT. Camel meat Food and Medicine. An article issued by Oman Daily Observer in cooperation with The Sultan Qaboos University. 2009. 